\title{
Stakeholder Relations Management as a Public Relations Tool for Socio-Economic Development in Nigeria
}

\section{Okechukwu Itanyi}

Executive Commissioner (Stakeholder Management) Nigerian Communications Commission, Abuja

Wilfred I. Ukpere

Department of Industrial Psychology and People Management, Faculty of Management, University of Johannesburg, Johannesburg, South Africa

E-mail: wikpere@uj.ac.za

\author{
Doi:10.5901/mjss.2014.v5n10p21
}

\begin{abstract}
No proper organization can function independent of its environment. Each is made up of an internal structure, and exists within a framework of interrelated system of relationships with key stakeholders such as competitors, donors, consumers, regulators, the media, and so on. Therefore, there is the need to depart from the traditional approach of influencing public opinion to a more modern and strategic approach of guarding public moods, disposition and judgement before even attempting to satisfy expectations. The objective of this study was to ascertain whether Stakeholder Relations Management can be used as a Public Relations tool for socio-economic development in Nigeria. The aim was to establish the veracity of the statement that stakeholder relations management is a public relations tool and if it could be used for socio-economic development of Nigeria. Data was collected from available literature on stakeholder relations management and public relations. Also the professional observations of the authors were also used. Good stakeholder relationship management which is one of the tools of modern public relations that foster a sense of joint ownership, prevents undue bureaucracy or industrial disputes, makes resources available, keeps information/knowledge and feedback flowing and enhances cooperation to achieve the desired outcome of socio-economic development. The study proposed that organizations have to evaluate the possibility of adapting and/or integrating the benefit of the emerging stakeholder management trends into their institutional framework. The management of organizations must realize that for their organizations to be competitive in the global economy, they have to leverage on these collaborative relationships with both internal and external systems in their networks to achieve results.
\end{abstract}

\section{Introduction and Background of the Study}

No organization is an island. Each is composed of an internal system of network, and exists within a framework of interrelated system of relationships with key stakeholders such as competitors, donors, consumers, regulators, the media, and so on. Some organizations may prefer to think of themselves as well equipped with all the resources necessary for their own sustenance. In reality such a view is too short sighted for success.

Value creation is the final objective of a company (Rappaport, 1986: 2-3; Mills and Weinstein, 2000: 79-93; Jensen, 2001: 8-21; Grant, 2002:1-2), and in order to achieve this purpose, the firm cannot ignore the context in which it operates. In fact, a network of relationships connects the company to a great number of interrelated individuals and constituencies, called stakeholders (Freeman, 1984: 46; Donaldson and Preston, 1995: 85-86; Post et al., 2002: 8-9). These relationships influence the way a company is governed and, in turn, are influenced by the company's behavior. In more depth, Post et al. (2002: 8-9) emphasize that "the capacity of a firm to generate sustainable wealth over time, and hence its long-term value, is determined by its relationships with critical stakeholders" and any stakeholder relationship may be the most critical one at a particular time or on a particular issue.

The concepts of stakeholders and publics are often used interchangeably. However, stakeholders are general categories of publics linked to an organization such as employees, investors and customers (Grunig et al, 2002:2). Grunig and Hunt (1984: 7-8) affirm that groups and individuals with any of the four types of linkage to an organization, enabling, functional, diffuse, or normative, can all be described as some sort of 'stakeholders'. Hence, Stakeholders belonging to the diffused linkage often identify themselves when the organization does something that affects them. These publics include members of the community, environmental groups, the media, voters and other groups that organize to face a 
situation (Rawlings \& Bowen, 2005:719; Grunig \& Hunt, 1984: 7-8).

More than that, Stakeholders are those without whose participation, the corporation cannot survive. This set of stakeholders includes capital suppliers (shareholders), employees, other resource suppliers, customers, community residents and the natural environment (Clarkson, 1995:106; Starik, 1995:204-217). Stakeholders are those individuals or groups that have a 'stake' in the firm (Caroll, 1993:22). They have been defined in a number of ways, including those individuals with implicit or explicit contracts with the firm (Donaldson and Preston, 1995:85); any group or individuals who can affect or is affected by the achievement of an organization's purpose (Freeman, 1984:52); those with a legitimate claim on the firm (Hill and Jones, 1992:133), and in a variety of other similar ways. In general, there is a consensus that stakeholders often include customers, employees, management, stockholders, creditors, suppliers, community, and sometimes even competitors (Schilling, 2000:224-242).

An organization being a set of inter-dependent relationships among primary stakeholders (Chakravarthy, 1986: 437-458; Donaldson and Preston, 1995:71; Evan and Freeman, 1998:75-93; Greenley and Foxall, 1996:105-116; Jones, 1995: 404-437), means that while an effective management of relationships with primary stakeholders can lead to more than just their continued participation in the firm, the inability to effectively manage relations among these groups may portend negative consequences for all primary stakeholders. Subsequently, in line with the resources-based view of the firm which argues that a firm's ability to out-perform its competitors is dependent on the inimitable interplay of human, organizational and physical resources over time (Amit and Schoemaker, 1993:179-191; Dierickx and Cool, 1989:15041511); many scholars now strongly believe that intangible, difficult-to-replicate resources must be the basis for business processes if a firm is to outperform its rivals and create value for shareholders. Some of these resources include among others long-term relationships with suppliers and customers (Atkinson et al., 1997:25-37; Teece, 1998:55-79).

Stakeholder management is about the management of the relationships with all stakeholders serving their interests efficiently and thus profitably in order to sustain and improve the contributions (resources) they provide for the organization's value creation. It's all about relationship and experience management and, business excellence (Scharioth and Huber, 2003:2-4). Effective management of relationships with stakeholders is crucial to resolving issues facing organizations. By using their influence, stakeholders hold the key to the environment in which an organization operates and the subsequent financial and operating performance of the organization. Therefore, a proper management of stakeholder relations is an emergent focus of public relations and organizational activities (Harrison, 2014).

Public relations is the communication acting on the part of an organization that supports the development and maintenance of mutually beneficial relationship between the organization and the groups with which it is interdependent (McKee and Lamb, 2009:1). In addition, Public relations has been recognised as a strategic communication process built on mutually beneficial relationships between organizations and the publics (Public Relations Society of America, 2014). Therefore, Corporations must recognize that the greatest stakeholder, the ultimate environmental constituency is society itself, to which such corporation are ultimately, and irrefutably answerable to (Starck and kruckeberg, 2000:59). Public relations practitioners are charged with learning how to communicate with, rather than to their publics. Organizations operate by consent of communities, which is their ultimate stakeholder (Starck and kruckeberg, 2000:5).

\section{Statement of the Problem}

Organizations currently function in a constant changing environment. These changes influence the organization decision making and strategy formulation. Also businesses have evolved from being purely profit driven to more recently towards a collaborative relationship. An organization is viewed as a socio-economic system where wealth is created through collaboration, which produces social and economic wealth. Furthermore, organizations are now evaluated by the level of how they relate with their publics as well as how they create wealth.

Since these collaborative relationships between organizations, publics and society have become increasingly important, it is understandable that the need to coordinate society has become important. Therefore, there is the need to depart from the traditional approach of the desire to influence public opinion to a more modern and strategic approach of guarding public moods, disposition and judgement before even attempting to satisfy expectations. Thus, one of the key challenges in public relations has been to develop and manage relationships with those who can influence target audiences.

\section{Objectives of the Study}

Using the concept of Public Relations (PR) as a reference point, this article makes a case for also integrating the stakeholder management tool into the concept for socio-economic development. The traditional public relations approach 
ranged from conducting press releases through lobbying, to celebrity campaigns on behalf of a sponsor or an interest. The goal however is to persuade the public, investors, partners, employees and other stakeholders to maintain a certain point of view about it, its leadership or organizational decisions. Therefore, the main objective of this paper is to establish that stakeholder management could be used as a public relations tool for socio-economic development. Other objectives of the paper are:

1. To establish the link between Stakeholder Management and Public Relations.

2. To determine how Stakeholder Management could lead to socio-economic development.

3. To redefine a new approach to Public Relations through the application of Stakeholder Management Strategy.

\section{Research Methodology}

The paper is a qualitative study which is based on secondary data. The study was carried out through the meta-analysis of reports on public relations and stakeholder management. Relevant literatures on public relations and stakeholder management were reviewed, which led to insight stimulating research.

\section{Theoretical Framework}

\subsection{Public Relations in Context}

Public relations consist of facilitating communication amongst various public groups. It can as well be described as a strategic conversation. Corporate and agency public relations differ. Corporate public relations can be visualized as being an in-house public relations department within an organization. On the other hand, public relations agencies are hired consultants that normally work on an hourly basis for specific campaigns or goals of the organization that hires them. In organizations like the Nigerian Communications Commission (NCC), Central Bank of Nigeria (CBN) and Nigerian National Petroleum Corporation (NNPC), for example, it is common to have both an in-house corporate public relations department and an external public relations agency that consults on specific issues. Government relations or public affairs is the branch of public relations that specializes in managing relationships with governmental officials and regulatory agencies. A few areas of concentration in public relations include: Industrial public relations, which communicate industrial results and business strategy; Consumer public relations, which involves gaining publicity for a particular product or service; Disaster Communications which is responsible for responding in a crisis; Organizational Communications which entails communicating within the company itself; and Government Relations, which is responsible for engaging government departments to influence public policy. Each case is characterized by common features such as press releases, newsletters, social events, social networking and social media, and so on.

\subsection{The Limitation of Traditional Public Relations}

What has emerged from the discussion so far is the inherent desire to influence public opinion. But what underlines achievement is basic understanding of the public moods, dispositions and judgment before even attempting to satisfy expectations. Thus, one of the key challenges in public relations has been to develop and manage relationships with those who can influence target audiences. This is the remarkable entry of public relations practitioners into the realm of stakeholder engagement and management.

\subsection{Stakeholder Management Concept}

The concept of stakeholder and public often are used interchangeably. However, Grunig and Repper (1992: 117-158) define stakeholders as general categories of public linked to an organization such as employees, investors and customers (Grunig et al, 2002: 2). Stakeholders belonging to the diffused linkage often identify themselves when the organization does something that affects them. These publics include members of the community, environmental groups, the media, voters and other groups that organize to face a situation (Rawlins and Bowen, 2005:719, Grunig and Hunt, 1984: 7-8).

The argument by Friedman (2000:2) that companies do not operate in a vacuum but rather are plunged in a universe of relationships with multiple stakeholders, when placed side-by-side with the demands of globalization, shows that the scenario in which companies operate has become even more complex, given the emergence of global groups of stakeholders. This coupled with an increased level of competition among firms, means that organizations must look for 
new ways to create a competitive edge.

Faced with increased globalization, Drucker (1989:2) believes that the management of any business must maintain its wealth-producing resources intact by making adequate profits to offset the risk of economic activity, ensuring a continuous increase in the wealth-creating and wealth-producing capacity of these resources. However, this responsibility demands a careful consideration of the costs of meeting these responsibilities and the benefits to be derived. Regrettably, organizations and businesses have been operating based on the traditionally held belief that the primary aim of the business is the protection of the interest(s) of these stakeholders.

While this view is accurate, it is to be noted that in a liberalized economy, stakeholders extend beyond the superficial immediate owners of the business. The need to ensure that the management of organizations adopt measures and policies aimed at promoting in equal measure the well-being of every stakeholder, prompted suggestions for a redefinition of the complex relationship existing between business organizations and the society (Sharplin, 1985: 2-4). It is evident from the above that "the survival and continuing profitability of the corporation depends upon its ability to fulfill its economic and social purpose, which is to create and distribute wealth or value sufficient to ensure that each primary stakeholder group continues as part of the corporation's stakeholder system" (Clarkson 1995: 107).

Whereas the internal stakeholders includes stockholders and employees, including executive officers, other managers and board members, the external stakeholders are all other individuals and groups such as customers, suppliers, creditors, government, unions, local communities and the general public, that have claims in the company (Hill and Jones, 2009:134-150). Johnson et al. (2008:156) further classifies external stakeholders into three major types, namely Economic stakeholders such as suppliers, competitors, distributors; Socio/Political stakeholders such as policy makers, regulators and government agencies who will influence social legitimacy; and Technological stakeholders such as key adopters, standard agencies, and owners of competitive technologies who will influence the diffusion of new technologies and the adoption of industry standards.

\subsection{The Strategy of Overcoming Public Relations Challenges through Stakeholder Relations Management}

The role of a stakeholder manager is broadly demarcated into the following six stages using the I-C-E cube model, namely Identification; Classification; Expectations; Influence; Communication; and Evaluation (Project Stakeholder Management, 2014). These roles are explicated in the following sections.

\subsection{Stakeholders Identification}

A fundamental technique used in both public relations and stakeholder management is to identify the target interest, and to tailor messages to appeal to each interest, bearing in mind that sometimes the interests are differing and conflicting hence the need to create several distinct but complementary messages.

Stakeholder theory identifies those who have a stake in an organization or a project. All audiences are stakeholders (or presumptive stakeholders), but not all stakeholders are audiences. For example, if an organization like the Nigerian Communications Commission (NCC) commissions, a public relations agency to create an awareness campaign on telecoms consumer affairs in order to find a solution to consumers issue, then NCC and the consumers associated with the particular issue are stakeholders, but the public or audience is anyone who is likely to influence the solution.

The first step in developing NCC's Project Stakeholder Management strategy is to identify the stakeholders. These are people or organizations that are actively involved in a project, or whose interests may be positively or negatively affected by execution or completion of the project. Overlooking positive or negative stakeholders can increase the likelihood of failure. Whatever list one produces will need to be re-visited during the project lifecycle as new information becomes available as the project progresses. In order to start the identification process the following inputs are needed, namely Project Charter; Procurement documents; Company information; and Lessons learned from previous projects. The outcome of these activities will basically be a listing of stakeholders, without analysing things at this stage.

\subsection{Classification of Stakeholder}

The list of project stakeholders can be very large, so we need to partition the list in a way that helps us to manage each stakeholder or group. One strategy is to map out all the stakeholders on a given project and partition them according to the following namely influence, which is the ability to control or affect the actions, beliefs and attitudes of other people; and interest, which is the state of being involved, responsible, attentive, affected, concerned and curious (Project 
Stakeholder Management, 2014). After considering all the classifications, one should be able to plot the stakeholders in a grid below.

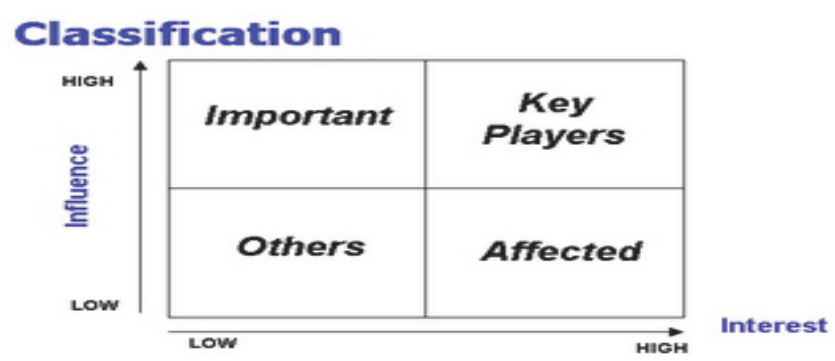

More dimensions could also be added by considering people's level of support for a given project. It is also pertinent to assess their level of motivation, and fit them into one of these categories, namely Allies; Supporters; Neutral; Reluctant and Opponents. The next will be to understand stakeholder's expectations.

\subsection{Understand Stakeholder Expectations}

To understand, quantify and document stakeholder's expectations in relation to the organization is an imperative, which so often leads to creating requirements that can be managed as part of the Scope management process. As a rule of thumb, no project can be fully understood from the outset due to the theory of progressive elaboration i.e. a situation where the project becomes clearer as time progresses (Project Stakeholder Management, 2014). Techniques for uncovering requirements are: In-depth Interviews; Focus Group Discussions; Facilitated Workshops; Survey questionnaires; Observations; Simulations and Prototypes.

Quite often, converting stakeholder expectations into requirements becomes challenging in which case the need to directly influence the stakeholders automatically arises curious (Project Stakeholder Management, 2014).

\subsection{Seek to Influence Stakeholders}

Although some stakeholders are very powerful people, a stakeholder manager probably knows more about the project than them. This gap can often lead to some stakeholder expectations not being met within the confines of a project. In cases like this, it is expedient to offer explanation early enough in an honest and transparent manner. Some Common Pitfalls are: Always find fault with deliverables; Not provide feedback on interim deliverables and milestones; Delay the approval process; Not provide any direction; Steal your team members; Undermine your authority with politics; Make a case against the project in public; and Starting a competing project.

Some stakeholders will certainly resist change. The best way to influence them to support your project is to educate them about the benefits of the project. A stakeholder manager should probe deep to discover possible sources of influence. Typical power bases may include formal reward and punitive measures.

One key strategy is to develop rapport by making people feel important, anticipating their expectations, and keeping them informed. Every person involved in a project is important to its success. A great way to gain commitment is to help them see the importance of what they are doing. It is important to keep people informed. No one likes surprises. Tell them what they need to know, when they need it. Remind team members about issues that are coming up and notify them if any plans change. It is also necessary to know what stakeholders expect. The more one understand stakeholders' needs, the better equipped one will become to meeting their expectations. It is also essential to inform stakeholders about what requirements will be met, and what requirements will not be met, and the reasons why. There is also a need to involve them in the creation of lessons-learned. Finally, one needs to be honest, and follow the code of professional conduct (Project Stakeholder Management, 2014).

\section{Communication}

On the average, stakeholder managers spend $80 \%$ to $90 \%$ of their time communicating. Thus management of communication with the various project stakeholders is very vital. Using different strategies for the different groups of stakeholders has proved useful. The box below is a generic approach for managing different interest groups. 


\section{Communication Strategies}

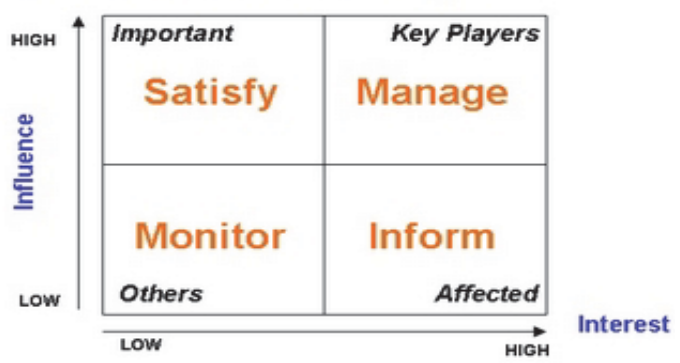

Source: Project stakeholder Management (2009).

It is imperative to manage key players closely and keep them fully engaged. More than that there is a need to keep important stakeholders satisfied. Do not burden them with too much detail. Try and keep affected stakeholders informed. Communicate regularly to check that no major issues are appearing. Make efforts to monitor other stakeholders. It is good to communicate, but do not bother them with too much information.

\section{Evaluation of Strategy}

As part of refinement process, periodic evaluation of the success or otherwise of the stakeholder management strategy of an organization, including update in the register, re-assessment of their interest and influence, should be carried out. The focal areas of probe are: whether the organization's stakeholder management strategy working; whether the organizational influence and communication is effective; and whether there are any update and appearance of new stakeholders.

\subsection{Mapping Public Relations and Stakeholder Management to Development}

Whether we are talking about Public Relations (PR) in its traditional form or integrating it with Stakeholder Management (SM), the bottom line remains achievement, which can translate into development or productivity. The variables in productivity, as being discussed in this paper, are essentially three, namely: Quality, Cost and Time. In a systematic project management methodology, trade-offs are allowed between two of the variables by holding one constant. For example, if a project suddenly places more emphasis on Time, then to achieve the desired result, the other two variables: Quality and Cost have to be adjusted accordingly.

According to Khanduja (2009), there can be two scenarios, namely either the delivery is production centric or quality centric. In production centric delivery system the focus will mainly be on the quantity produced. The performance will purely be measured based on the volumes produced. The company will be using productivity metrics focusing on increasing production all the time. In terms of the quality centric delivery system the focus will be more on the number of good pieces produced. This may enforce quality checks at each station. The performance will purely be measured based on good pieces produced irrespective of howsoever high the number of overall pieces produced. The company will be using quality metrics focusing on increasing quality all the time (Khanduja, 2009).

It can be argued that there is no competition in the first case where an entity is production centric. The risk of failure in the market is high since the company is not quality focused and hence rejections and failures at customer site will definitely be higher.

One would notice a high competition in second case. Any rejection at customer site is counted as failure of quality. However, the overall risk is very low of getting rejections or failures at customer site since all the bad pieces have already been detected and discarded by the quality control department.

Through constant iteration and refinement processes, the economic index for a particular production is developed to the satisfaction of project owners. But this is only one aspect of the advantages of good public relations and stakeholder relations management. For the fact that performance or productivity is tied to reward, one can make a moderate assertion that good public relations and stakeholder relations management promote social integration. As has been mentioned severally earlier, excellent communication lends itself a motivated team; motivated workforces ultimately strive for high performance, high achievement and so on. From the foregoing, it is obvious that Stakeholder Relations Management is an emerging Public Relations tool that can foster socio-economic development. 


\subsection{Benefits of Stakeholder Relations Management}

The business benefits of effective engagement are now well known and well documented. A number of studies have found a clear correlation between stakeholder relationship quality and financial performance (Waddock and Graves, 1997: 250; and Svendsen et al, 2001), sustainable wealth and long term value (Post et al, 2002: 8-9), and corporate reputation (Dowling, 1994: 8). Svendsen (1998:1) argues the case for competitive edge as an outcome of effective stakeholder engagement and stated: "as paradoxical as it sounds, one way to succeed in a highly competitive globalised economy is to cooperate".

The central claims for an integrated approach to stakeholder engagement arguably centres primarily on benefits to the organization essentially on the view that "incorporating stakeholder views in decision making processes enhances organizational performance and commitment" (Simmons, 2003: 1). In this context, Hitt et al (2001: 191) point to the major post 1980s contributions made to stakeholders theory by Ackoff and Churchman (1947: 304-332), who applied a system theory approach describing organizations as open system and acknowledging their interdependency with external networks; and Katz and Kahn (1996: 26-27) who developed organizational frameworks defining the organization relative to the system around it.

There is indeed substantial evidence in the stakeholder and communication management literature to suggest that enlightened organizational strategy-making is best informed by a process of continuous dialogue with stakeholders and that "the social performance of any business should be judged not only by what it does, but by the extent to which it facilitates interested parties in negotiating what it does" (King, 1998: 43). According to Savitz and Weber (2006: 63), doing business in this emerging world of freer, more independent, wired and filled with powerful, vocal stakeholders demand a degree of accountability. This means that everyone knows your business, has an opinion about it and feels that he or she has the right to express that opinion and try hard to change your behaviour. This is a new era for business in which responding to the demand of sustainability is a necessity, not an option.

Gardner (2004:4) posits that in operational definitions of sustainable corporate practices, corporate social responsibility and the allied notion of corporate citizenship. Authors such as Dunphy et al (2000: 3-18) and Kok, Weil, McKenna and Brown (2001: 285-297) stress the need to embrace corporate system and practices which reflect the interests of a wide range of stakeholders or constituents. They argue that it is these parties engaged in a productive dialogue that can provide requisite knowledge required to resolve the longer term challenges of sustainable development triple bottom line performance. The sustained corporation must demonstrate the ability to learn from stakeholders and previous mistakes, through a continuous process of consultation, measurement, auditing and reporting.

The organization reports many benefits of having stakeholder engagement embedded as a core function and the adoption of a strategic and systematic approach, including, enhanced trust and credibility through improved relationships at various levels of the organization, better outcome for communities, stakeholder and the environment through early and genuine engagement, faster (regulatory) approvals, with stakeholder managers fostering organizational interaction and playing an important role in issues resolution through new initiatives; improved service for major and significant stakeholders through dedicated resources and early open exchange of information; and better decision making through corporate intelligence, consistent messages and understanding of organizational position on matters (Ferrari, 2008: 5).

\subsection{Stakeholder Management Strategy in the Nigerian Communications Commissions}

The following are examples of stakeholder management strategies adopted at the Nigerian Communication commission:

\subsection{Telecoms Consumer Parliament and Consumer Outreach Programme}

One of the ways this strategy is being carried out is through Outreach programmes like the Telecom Consumer Parliament (TCP) and Consumer Outreach Programme (COP). These programs are implemented in State Capitals and Urban Centres. At these fora stakeholders deliberate on topical industry issues touching on Consumers' interests. These fora discussions serve as a feedback to the Commission and it translates into policy action and further regulatory intervention by the Commission. These fora are primarily targeted at consumers; all current issues affecting consumer comfort and satisfaction are addressed at these events. These events are continuous in nature. 


\subsection{Industry Working Group on Multiple Taxation and Industry Working Group on Corporate Governance}

The Commission formed an Industry Working Group made up of the various operators in the industry to look at Corporate Governance and multiple taxation issues. Through the Industry Working Group on Corporate Governance, the Commission organized a consultative forum on Corporate Governance in the telecommunications industry. The forum was aimed primarily at formulating a Corporate Governance Code preparatory to launching it for the industry. Also, the Commission through the Industry Working Group on Multiple Taxation organized a stakeholder forum on multiple taxation, which is aimed primarily at the three levels of government (local, state and federal), and their agencies. The Industry Working Group (IWG) on Multiple Taxations seeks the discontinuance of illegal taxes/multiple regulations on telecommunication infrastructure as a strategy to deepen ICT Penetration and improve the Quality of Service (QoS), National Security and overall socio-economic development of the country as well as facilitate the designation of such infrastructure as Critical National Infrastructure (CNI).

The Commission has also organized other stakeholder fora where stakeholders are gathered together to discuss issues that affect the industry. Some of these fora that have been organized include:

\subsection{Stakeholder Consultative Forum on Child Online Protection}

The Commission conceptualized the forum to enable stakeholders design appropriate guidelines to prevent, check and reverse the negative consequences of online interactions because 60 percent of the 1.5 billion participants of online interaction are children. NCC will utilize the resolutions of the forum to formulate guidelines for child online protection.

\subsection{The Nigeria Internet Governance Forum (NIGF)}

This is a renewed collaborative effort of internet stakeholders in the country to help provide a coordinated mechanism for domestic multi-stakeholders participations in the regional and global internet governance, and to help facilitate partnerships, coalitions and dialogues that redefine Nigeria position at regional and global IGF meetings. The forum aims to provide a sustainable National forum and structure that engages industry, government, law maker, academia, civil society and all domestic stakeholders in the strategic national debate on Internet Governance issues.

\subsection{Stakeholders Consultative Forum on Current Level of Competition in the Nigerian Telecommunications Sector}

Experts have identified a number of anticompetitive practices in the nation's telecoms sector which include predatory pricing, which involves the practice of providing services that are below cost to drive competitors out of a market, so as to monopolize the market; and vertical price squeeze, having to do with a firm demanding a price for the essential facility that is so high that it is not possible for a competitor to operate profitably or survive. Others are refusal to share infrastructure, characterized by a dominant operator's refusal to supply an essential facility to a competitor; and cross subsidization. It was in a bid to address all these factors that would lead to unhealthy competition in the industry that the NCC recently organized a stakeholder's forum where representative of telecoms operators expressed what they consider as anti-competitive practices in the industry with recommendations on the way forward.

\subsection{Broadband Forum}

This was organized because of the desire for faster deployment of broadband services to all parts of the country for quality services delivery. The forum was organized by publishers of eWorld Magazine in collaboration with the Nigerian Communications Commission (NCC). The event was a platform for stakeholders in the industry to look at issues of broadband deployment, especially the gray areas the regulators need to touch in order to reach the required broadband level in penetration, growth and access. Also, stakeholders at the event were expected to articulate other major challenges involved in the deployment process and also proffer solution that would fast-track Nigeria's journey to ubiquitous broadband services.

\subsection{Stakeholders Forum on Review of Interconnection Rates}

Stakeholders, including all the telecom operators were gathered recently to review a final draft report on new interconnection rate prepared by the NCC's consultant. The forum organized by the NCC was with a view to harmonizing 
views of the operators to arrive at a final decision on the new interconnection rates for the industry. The report was made available to all operators and they were given seven days to review and send their input to the regulator, after which the NCC came out with new interconnection rates.

\section{Research Findings}

Organizations operate in a continually changing environment and these changes affect how organizations formulate and implement their strategies. Furthermore, businesses are changing from being more profitable to more of a collaborative/mutual relationship.

Since these mutual relationships have become increasingly important, there is the need to coordinate the society. This requires the departure from the traditional approach of public relation to a more modern strategic approach.

Good stakeholder relationship management which is one of the tools of modern public relations, foster a sense of joint ownership, prevents undue bureaucracy or industrial disputes, makes resources available, keeps information/knowledge and feedback flowing, and enhances cooperation to achieve the desired outcome of socio economic development.

\section{Conclusion and Recommendations}

This treatise has provided useful insight into the concept of public relations. It has examined the dynamics of the profession and proposed the strengthening of the endeavour through stakeholder relations management. The practicality of achieving socio-economic growth through the fusion of stakeholder relations management into public relations has been discussed.

The observations of one of the present authors working both for the State and Federal governments in Nigeria, gives credence to this proposition. Organizations have to evaluate the possibility of adapting and/or integrating the benefit of the emerging stakeholder management trends into their institutional framework.

Based on the foregoing, the following recommendations are worth considering:

1. Public relations managers/practitioners should acquire stakeholder relations management skills in order to keep abreast with the modern trends.

2. The management of organizations must realize that for their organizations to be competitive in the global economy, they have to engage in collaborative relationships with both internal and external system in their networks.

3. Continuous dialogue, communication and feedback should be encouraged within and outside organizations to reduce process/project downtime and improve quality delivery.

4. Stakeholders/public should always contribute to policy formulation and implementation.

\section{References}

Amit, R.H. \& Schoemaker, P.J.H. (1993). Strategic Assets and Organizational Rent. Strategic Management Journal, 14(1):33-46.

Atkinson, A., Waterhouse, J., and Wells, R. (1997). A Stakeholder Approach to Strategic Performance Measurement. Sloan Management Review, 38(3):25-37.

Carroll, A.B. (1993). The Pyramid of Corporate Social Responsibility: Toward the Moral Management of Organizational Stakeholders. Business Horizons, 34(4):39-48.

Chakravarthy, B. (1986). Measuring Strategic Performance. Strategic Management Journal, 7:437-458.

Churchman, C.W. \& R.L. Ackoff (1947). An Experimental Measure of Personality. Philosophy of Science, 14(4):304-332.

Clarkson, M. (1995). A Stakeholder Framework for Analyzing and Evaluating Corporate Social Performance. Academy of Management Review, 20(1):92-117.

Dierickx, I. \& Cool, K. (1989). Asset Stock Accumulation and Sustainability of Competitive Advantage. Management Science, 35(12):1504-1515.

Donaldson, T. \& Preston, L.E. (1995). The Stakeholder Theory of the Corporation: Concepts, Evidence, and Implications. Academy of Management Review 20(1):65-91.

Dowling, G.R. (1994). Corporate Reputation: Strategies for Developing the Corporate Brand. London: Kogan Page.

Drucker, P.F. (1989). The Practice of Management. Heinemann Professional.

Dunphy, D., Benveniste, J., Griffiths, A., and Sutton, P. (2000). An introduction to the sustainable corporation. In Sustainability: The Corporate Challenge of the 21st Century (Dunphy D (eds)), Crows Nest: Allen and Unwin.

Evan, W. and Freeman, E. (1998). A Stakeholder Theory of the Modern Corporation: Kantian Capitalism, In Ethical Theory and Business, Beauchamp T. and, Bowie N (eds.), NJ: Prentice-Hall. 
Ferrari, C. (2008). Water Corporation Stakeholder Engagement Framework. Summary prepared for the Corporate Public Affairs Institute Group. [Online] Available: http://www.accpa.com.au/downloads/Ferrari_Day2\%20session\%20/IISEF_Summary/pdf (Retrieved 19 May 2009).

Freeman, R.E. (1984). Strategic Management: A Stakeholder Approach. Boston: Pitman.

Gardner, S. (2004). Being Strategically Good: Thoughts on Social Responsibility, Citizen and Stakeholder Engagement in Australian Companies, available from School of Management, Faculty of Business and Public Management, Edith Cowan University, Perth.

Grant, R.M. (2002). Contemporary Strategy Analysis: Concepts, Techniques and Applications, Oxford: Blackwell.

Greenley, G. \& Foxall, G. (1996). Consumer and Non-Consumer Stakeholder Orientation in UK Companies. Journal of Business Research, 35(2):105-116.

Grunig, L.A., Grunig, J.E., \& Dozier, D.M. (2002). Excellent public relations and effective Organizations: The study of communication management in three countries, New Jersey: Lawrence Erlbaum Associates.

Grunig, J.E., \& Repper, F.C. (1992). Strategic management, publics and issues. In J. E. Grunig (Ed.), Excellence in public relations and communication management, Hillsdale, NJ: Lawrence Erlbaum Associates, Inc.

Grunig, J.E. and Hunt, T. (1984). Managing Public Relations. Orlando, FL: Harcourt Brace Jovanovich.

Haberberg, A. and Rieple, A. (2001). The Strategic Management of Organizations, Harlow: Prentice-Hall.

Harrison K. (2014). You can earn promotion by learning nine essential PR management skills. [Online] Available: www.cuttingedgepr.com (20 February 2014).

Hill, C.W.L and Jones, G.R. (2009). Theory of Strategic Management with Cases, South-Western: Cengage Learning.

Hill, C.W.L. and Jones, T.M. (1992). Stakeholder-Agency Theory. Journal of Management Studies, 29(2): 131-154..

Hitt, M., Freeman, R. and Harrison, J. (2001). The Blackwell Handbook of Strategic Management, New Jersey: Wiley-Blackwell Publishers Limited.

Jensen, M.C. (2001). Value Maximization, Stakeholder Theory, and the Corporate Objective Function. Journal of Applied Corporate Finance, 14(3):8-21.

Jones, T. (1995). Instrumental Stakeholder Theory: a Synthesis of Ethics and Economics. Academy of Management Review, 20.

Katz, D. \& Kahn, R. L. (1996). The Social Psychology of Organization, New York: Wiley.

Khanduja J. (2009). Productivity Metrics vs. quality metrics- quality assurance and project management. [Online] Available: http://www.itknowledgeexchange.techtarget.com (Retrieved 25 February 2014).

Kim, H. (2013). Stakeholder relations management is a key skill, accessed from http://www.cuttingedgepr.com (Retrieved 14 February 2014).

King, A. (1998). The Social Performance Uncertainty Principle. Corporate Reputation Review, (1):43-46.

Kok, P., van der Wiele, T., McKenna, R. \& Brown, A. (2001). A Corporate Social Responsibility audit within a quality management framework. Journal of Business Ethics, 31(4):285-297.

McKee, K.B. and Lamb, F.L. (2009). Applied Public Relation: Coded 2 Stakeholder Management,( 2nd ed). New York: Font Ledger.

Post, J.E., Preston, L.E., and Sachs, S. (2002). Redefining the Corporation: Stakeholder Management and Organizational Wealth California: Stanford Business Books.

Rappaport, A. (1986). Creating Shareholder Value: The New Standard for Business Performance. New York: Free Press.

Rawlings, B., \& Bowen, S. (2005). Publics, in Heath, R.L., Encyclopedia of Public Relations. Thousand Oaks: Sage.

Savitz, A. \& Weber, W. (2006). The Triple Bottom Line: How today's Best Run Companies Are Achieving Economic, Social and Environmental Success - and How You Can Too. San Francisco: Jossey.

Scharioth, J. \& Huber, M. (2003). Achieving Excellence in Stakeholder Management. Berlin/Heidelberg: Springer.

Schilling, M.A. (2000). Decades Ahead Of Her Time: Advancing Stakeholder Theory through the Ideas of Mary Parker Follett. Journal of Management History, 6(5):224-242.

Seitel, F.P. (2007). The Practice of Public Relations, Upper Saddle River. NJ: Pearson Prentice Hall.

Sharplin, A. (1985). Strategic Management. New Jersey: McGraw-Hill.

Simmons, J. (2003). Balancing Performance, Accountability, and Equity in Stakeholder Relationships: Towards More Socially Responsible HR Practice. Corporate Social Responsibility and Environmental Management, 10(3):129-140.

Starck, K. \& Krickeberg, D. (2000). Public Relations and Community: A Reconstructed Theory Revisited, in Heath, R.L., and Vasquez, G.M., Handbook of Public Relations, London: Sage.

Starik, M. (1995). Should Trees Have Managerial Standing? Toward Stakeholder Status for Non-Human Nature. Journal of Business Ethics, 14(3):207-217.

Svendsen, A. (1998). The Stakeholder Strategy: Profiting from Collaborative Business Relationships. San Francisco: Berrett-Koehler.

Svendsen, A.C., Abbott, R.M. \& Wheeler, D. (2001). Measuring the Business Value of Stakeholder Relationships Part One, the Centre for Innovation in Management. [Online] Available: www.stakeholder360.com/c7.htm (Retrieved on 18, June2013).

Teece, D. (1998). Capturing Value from Knowledge Assets: The New Economy, Markets for Know-How, and Intangible Assets. California Management Review, 40(3):55-79.

Waddock S, Graves S. (1997a). The corporate social performance-financial performance link. Strategic Management Journal, 18(4):303319.

Public Relations Society of America (2014). What is Public Relations? [Online] Available: http://www.prsa.org/ (22 February 2014).

Project Stakeholder Management, (2009). Best Practices: Self Management [Online] Available: http://www.projectstakeholder.com (22 February 2014). 